\title{
Small-scale fisheries in Greenlandic planning - the becoming of a governance problem
}

Rikke Becker Jacobsen ${ }^{1,2}$

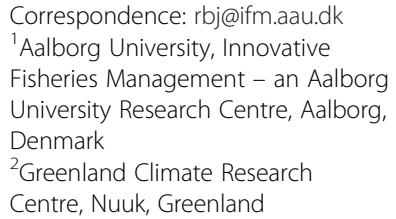

Correspondence: rbj@ifm.aau.dk ${ }^{1}$ Aalborg University, Innovative Fisheries Management - an Aalborg University Research Centre, Aalborg, Denmark

${ }^{2}$ Greenland Climate Research Centre, Nuuk, Greenland

\begin{abstract}
This article analyses an ongoing planning process in Greenlandic fisheries governance aiming to reform the coastal Greenland halibut fishery. It examines the way certain truths about this fishery and the need for reform are produced up to and in the final policy document 'regulation concerning the coastal fishery for Greenland halibut'. Findings highlight the way the small-scale Greenland halibut fishery system becomes a particular governance problem with respect to particular contextual meanings of sustainability and long-term planning. The article then examines whether this governance problem could also be understood as primarily a problem to a certain 'governmentality' mode of governance. Whereas some fishery studies document how governmentality modes of governance in fisheries succeeds in transforming subjectivities, this study offers a view into the process that might go before successful governmentality: The process whereby a selected fishery becomes subjected to planned out-phasing through a combined construction of fleet and human identity.
\end{abstract}

Keywords: Fisheries governance - Governmentality, Long term management plans, Small-scale fisheries - Greenland

\section{Introduction}

Governmentality analyses of the way actors and discourses manage to make 'something you can govern by the help of identity formation' have provided a fruitful frame for analyzing the way people govern themselves and others. As a mode of governance, governmentality has been historically connected to the nation-state, the democracy and the imagery of populations that made the well-being of this population the primary goal of governance endeavours (Foucault 1994a, 217). Governmentality refers to a type of governance that takes place through the general management of 'men and their relations' to a multiplicity of actors and phenomena. It is a governance mode that acts in conjunction with the 'free' action of self-governing subjects and multiple tactics are central to its working (Foucault 1994a, 209). Governmentality is about how you make actors govern themselves by shaping and structuring their selves and actions according to specific ideas or ideals, and hereby, the construction of truths and identities by a government regime provides a framework for analyzing techniques of governance.

This article takes the theory of governmentality as a point of departure for analyzing the 2012 reform of the coastal commercial fishery for Greenland Halibut in Greenland. 
This reform grants individual transferable quotas (ITQs) to a relatively small group of vessels in the fishery and introduces a closure of new access to fishery on a shared quota performed by a relatively large group of small dinghies, dog-sledges and snow mobiles. The article applies the theory of governmentality to examine the articulated goals and rationalities of the reform and it examines how and why the future exclusion of the relatively more small-scale modes of production becomes part of a long-term planning solution in a reform that aims to improve a perceived situation of low profitability and problems of biological sustainability in the fishery. The questions the article seeks to answer are: 'how are the truths about human and fleet identities and economies in the current fisheries constructed in the reform?' and 'can these constructions be understood as arising out of governmentality challenges posed by the fishery to the centralized governance regime?' Secondly, the article builds on observations pertaining to the problem of 'governability' (Jentoft 2007; and Chuenpagdee 2009a, 2009b; Song and Chuenpagdee 2010) and seeks to draw a connection between the workings of governmentality, the limits of governability and the future exclusion of certain fisheries.

The article identifies three problems of governmentality that the centralized management regime seeks to address: One relates to the perceived economic behaviour of the participants in the fishery and the other to their de-facto influence on total allowable catch (TAC) policy. Thirdly, the article argues that issues of future exclusion and social justice in relation to ITQ implementation have had little influence on the decisionmaking as low monetary incomes and an assumed poverty problem of most participants came to define the key moral problem as a problem of necessary change.

\section{Theory and conceptual framework: governmentality and exclusion in the context of neoliberal fisheries governance}

The legacy of Foucaultian governmentality-thinking is implicit in some fisheries governance studies. There are similarities between Foucault's observation that with modernity humans became envisaged as population to be governed and Roepstorff's (1998) observation that modern states attempts to govern fisheries are equally connected to the perception of fish as abstract populations that have such an inherent quality as a maximum sustainable yield. Yet, the fish resource can only be controlled indirectly and so, historically, the disciplinary problem was soon transferred to the human agents in control of its harvest mortality. Thus it is widely recognized today that what you do in reality govern in fisheries governance is human behaviour. Bavington has argued that particularly the 1990'ies realization of the complexities within the natural system had governors redirect their gaze towards human actors, believing they are 'less complex and more determined by causal or statistical laws' (Bavington 2010, 107).

It is observed that fisheries management in the western world has turned industrial fisheries into management-fisher hybrids - or 'Cyborgs' as Johnsen et al. (2009) coin it. They argue that the relations that make up fisheries have become increasingly formalized and mechanized as the 'unmanageable' were made manageable. Still, according to fishermen themselves and other analytical observers, fishermen still tend to form very diverse groups in terms of their values and actions (Christensen and Raakjær 2006). A study of fishermen's perception of fleet categories throughout Europe showed that management categories tend to form and reorganize fisheries and fishing activities as 
fishers respond to the rules-in-place when they physically (re)build and (re)equip their boats (Wilson and Jacobsen 2009). Thus, fisheries governance as a type of governance activity has for some time been moulding its object of governance (also recognized by Jentoft 2007) and in the process, one may argue, self-identification and management classification have become intertwined.

In the context of New Zealand fisheries management, Massey (2004) has analyzed discourses of 'sustainable management' as an expression of governmentality in the sense that they have transformed stakeholders into subjects bound to a commercial discourse. Bavington (2010) and Carothers (2010) have observed that neoliberal fisheries governance discourses envisage a new type of fisher: That of the self-managing, profitseeking, detached and fully professionalised business entrepreneur. In line with much governmentality thinking, Bavington observed that the internalization of control through identity work was a means to increase the effectiveness of the Newfoundland fisheries governance system after the cod collapse. So he for example observes:

Managerial interventions in the cod fishery now work by involving rather than excluding fishermen, once they have been licensed ... Management now operates on the identity of fishing people - attempting to turn them into technicians for fisheries science and (self-) managing entrepreneurs'. (Bavington 2010, 113).

By implication, a range of studies now assert, from different but compatible perspectives, that modern fisheries governance have become possible through the discursive and material construction and de-facto promotion of certain types of (self)governable subjects. The concern for profitability and the introduction of ITQs can probably be viewed as a persistent trend in many fisheries governance discourses. Since the 1980'ies market-based fisheries management systems based on ITQs have gradually replaced traditional state-based command and control regimes in developed-nations fisheries across Oceania, North America and Europe (Valle et al. 2006). The described experiences and estimated effects of ITQs have varied and so for example has the Dutch system, that combines ITQ with a co-management system, been positively evaluated by participating fishers (Symes et al. 2010), whereas evaluations are highly diverse in the Icelandic case (e.g. Pàlsson and Helgason 2000). On a universal level, advocates have argued for the advantages of ITQ in terms of efficiency and conservation while critics have questioned these advantages and raised general issues of social fairness and effectiveness. (Bromley 2008; Pauly 2008; Macinko and Bromley 2004). ITQs tend to present tradeoffs between economic efficiency and other socio-economic concerns such as for example community survival; tradeoffs that have been addressed differently by different nations (de Valle et al. ibid).

While governmentality-inspired fishery governance studies point to examples where neoliberal governance regimes have been successful in moulding the subjects to be governed, other fisheries governance studies have been concerned with the problem of 'governability' and over-ambitious governance ambitions (Jentoft 2007; Jentoft and Chuenpagdee 2009a, 2009b; Song and Chuenpagdee 2010). These touch upon the problem of actual limits of governability and have invested considerable effort into understanding and asserting different degrees of governability pertaining to a given fisheries system. Essentially they promote recognition of the fact that fisheries management cannot, and therefore should not, aim to 
control every feature of inherently uncontrollable systems. Drawing on 'interactive governance theory' (Koimann 2005), these works exhibit a certain plea for a more gentle approach that accepts the limits of governability (see for example Jentoft 2007, 361) and a normative literature has thus emerged that argues that not only can we not manage to perfection our attempts at doing so may even be harmful.

Based on the Greenlandic case, this article is theoretically concerned with the way human and fleet identities are constructed in and for a planning process with a particular emphasis on how these identities are constructed around governance problems articulated in the planning process itself. Theoretically, the analysis unfolds around a central aspect of governmentality observed by Foucault: That governance in its most economic form takes place as a 'conduct of conduct' whereby subjects-to-be-governed are cultivated that will, in all freedom and voluntariness, act in accordance with the way the governors, if their rationalities ever had a face, would like them to act. A relationship of power is an 'action upon an action, on existing actions or on those which may arise in the present or the future' (Foucault 1982, 214) and 'the exercise of power consists in guiding the possibility of conduct and putting in order the possible outcome' (Foucault 1982, 214). The 'subject' is not an essentialist category in this view where the very way people see themselves and choose to act become a central space of interference for a governance regime. This article investigates how the subjectivities in the coastal fishery for Greenland Halibut in Greenland are first interpreted, and thus constructed, by the centralized governance regime and asks if the fishery can be said to pose a challenge to the 'soft' type of governmentality governance, whereby subjectivities that act in accordance with the new government regime are successfully created. The conclusion is affirmative and the article thus primarily offers the perspective of describing a process of out-phasing aimed at that which 'governmentality realizes it cannot govern'; the subjectivity of which is not to be changed and the conduct of which is not to be conducted.

\section{Method}

This article is part of a Ph.D. study of Greenlandic fishery governance institutions based on fieldwork and qualitative methods. A total of sixteen months of fieldwork was conducted in Nuuk from 2010 to 2012 Three months with half a week of participatory observation of the everyday work of the Ministry of Fishing, Hunting and Agriculture under Greenland Self-rule was arranged and informal contact was since sustained and data collected through informal conversations. For the remaining time the author has worked every day from the Greenland Institute of Natural Resources (GINR) which has provided rich access into observing formal and informal interactions between the managers, scientist, fishers and fisher representatives that make up the centralized part of the everyday fisheries governance system of Greenland. This system can be characterized as a closely knit field with regular and often informal contact between scientists, minister, fishery ministry and stakeholder organisations. Field notes with observations of meetings, summaries of informal conversations as well as public letters and speeches are used as data. The 'new regulation' and its drafts and background papers together with observations of the working group that formulated these, are particular central to this article. From this data 'identity construction' is identified by systematically comparing passages where the fishery is debated and described, noticing regularities as well as 
inconsistencies. The 'problem' of this coastal Greenland halibut fishery was very prevalent in the governance field and came to my interest as a result of an open approach as to what could eventually constitute data, method and theory (Wadel 1991) where this particular research problem started as an investigation of a problem 'taken for granted' in the Ministry.

\section{The coastal commercial fishery for Greenland Halibut and current management}

The commercialization and modernization of fisheries constitute the history of Greenland's industrialization and today, Greenland halibut is the second most important sea-food export article in Greenland. The coastal part of this commercial fishery takes place at the deep fiords of the west coast of Greenland in the three management districts of Upernavik, Ummannaq and Ilulissat where long lines are set from cutters and dinghies in the open water seasons and from dog sledges and snow mobiles on the ice in the wintertime. A general intensification of the fishery occurred since the 1980s and today the fishery is seemingly characterized by a relatively large number of participants with heterogeneous types of socioeconomic behaviour. The coastal fishery for Greenland halibut is generally poorly understood besides from what can be deduced from catch, trade and income statistics, but one indication of the diversity is visible from the 2009 sale statistics showing that a small percentage of the fishery's participants catch and sell most of the total catch while a very large group catch and sell very little (see also Table 1 in section seven). A study conducted in 2011 of the social impacts of the new regulation indicates that within the Upernavik district alone, several different types of 'socio-economic' systems are at play (Delaney et al. 2012). These range from systems where Greenland halibut is the sole production activity of companies or individuals to where Greenland halibut is only caught and sold when the fisher/hunter is in need of cash to buy consumption goods or to finance hunting activities. The small size of sales of Greenland halibut in some villages may thus be counterweighed by their importance in underpinning a mixed economy based on hunting and self-sufficiency in regions with few alternative employment possibilities.

The commercial coastal fisheries were first restricted by TACs in 2007. Three separate TACs are now provided for the three different management districts based on biological advice that presupposes that Greenland halibut seldom return to the off-shore banks to reproduce once they have entered the deep fiords (Roepstorff 1998). When presenting its scientific advice, GINR therefore often represent the inshore fiords as 'banks' in which fish left in the fiords are fish left to grow, but never to spawn (personal observation). The TACs are, up to the new regulation, fished on a common quota and access to the fishery is obtained by means of license to this Olympic fishery. In 2009 the licensed fleet consisted of 151 vessels above eight meters and about 1100 small entities, which is a term that covers boats under eight meters/dinghies, snow mobiles and dog sledges. Licenses are granted to companies or individuals, but the actual number of participants is expected to be somewhat higher than the number of licenses granted as the Ministry and the Greenlandic Fisheries Licence Control (GLFK) are aware of instances where several persons or family members fish on the same license, probably a result of an introduced license fee (202 Euros) per fished specie in 2010. The smallscale fishery conducted by numerous actors from settlements scattered across great distances in the vast management districts is notoriously difficult to monitor and control 
for the management system (personal observation of meetings with GFLK managers). Thirteen control officers together cover the inshore fishery of Greenland of which four are responsible for the areas coinciding with the Greenland halibut management districts. Dinghies are not registered, making physical monitoring difficult, and it can be difficult to get a precise picture of the fishery system from the centralized 'gaze' of the administration.

\section{The new regulation}

'Isn't the most general of political problems the problem of truth?' Foucault once asked from the position of an observer of governance (1994b, 233). I would argue that to those responsible of managing the coastal Greenland halibut fishery, the truth was indeed a problem. Not as in a question as to 'what is the truth?' about a complex socioeconomic system, but as a real, severe and true problem with the Greenland halibut fishery and what to do about it. When I started observing and participating in the everyday work of the Fisheries Department (FD) at the Ministry, the truth was already there as a premise for the need to act as the FD had been given the task by the Minister of Fishing, Hunting and Agriculture to investigate how best to implement an ITQ system into the coastal fishery for Greenland halibut. During its investigations FD followed the common practice of consulting the fishers' organisations (KNAPK, GA), the larger fishing companies (Polar Seafood and Royal Greenland A/S) and the municipalities' organisation (Kalaallit Nunaanni Kommunit Kattuffiannit (KANUKOKA)). Yet the very decision on introducing ITQ's was in practice irrevocable as it formed the very mandate for the work to be done. The vision of the new regulation was to address, in the words of FD, the dual goal of simultaneously securing biological sustainability and a sound economic development in the fishery by reducing the numbers of fishers to a number where the participating fishers 'could make a living of it'. These goals are visible in two of the three official goals of the final proposal for the new regulation:

The objectives of the final new regulation for the coastal fishery for Greenland halibut are:

- A structural adaptation of the fishery that will in the long term guarantee the participants an economically viable fishery.

- To show consideration of small and large vessels in the fishery so that these do not compete directly with each other.

- That the number of entities is reduced and that the stress on the biological advice is reduced.

(Medlem af Naalakkersuisut for Fiskeri, Fangst og Landbrug 2011).

A Greenland halibut management plan working group (WG) within the Ministry was established with the mandate to explore the possibilities in terms of transferability and principles for distributing the ITQ's. Soon however, it was realized by the leadership in FD that if every participating vessel was to have an individual share of the TAC in the form of a vessel quota, that share would be so small that it would not 'make any sense'. GFLK also observed that it would be an administrative nightmare to keep track of individual quotas for those participants who fish only a few tonnes a year. The leader group within FD therefore soon convinced 
the Minister not to distribute individual vessel quota to the very smallest entities the dinghies and dog sledges. These should instead continue to fish on a common Olympic quota. The TACs of the three management districts would therefore in the future be divided between ITQ holders and those with a license to fish on a common quota - each group receiving a fixed percentage of the TAC. Where exactly to draw the line between large and small entities was difficult to decide upon for the managers. They knew this was a fundamental political decision, but charged with the mandate of making the necessary recommendations they sought solution on technical grounds looking at what was administratively possible (personal communication with WG members and observations of WG meetings). The limit was eventually drawn at six meters.

In practice, the new regulation which emerged implies that the relatively 'larger entities' in the coastal fisheries are invited into a game of consolidation where they are to compete and buy each other up within a set limit of maximum ownership of $5 \%$ of the entire TAC. ${ }^{a}$ The dinghies, sledges and snow mobiles will continue to fish on an Olympic quota. Meanwhile, the problem of how to reduce the small scale fishers was not really solved by this solution since the reduction of the majority was no longer to happen automatically through an ITQ consolidation process. This became a main concern for the working group behind the new regulation which, having to respond to the political wish for general reduction, eventually suggested that the very small entities were to be gradually reduced by not allowing for new access to the fishery. In the final regulation a general closure of access to this type of fishery was therefore introduced for an unknown time period until the number of participants is reduced (Medlem af Naalakkersuisut for Fiskeri, Fangst og Landbrug 2011).

The new regulation will start a structural reform that can in the long run - if implementation allows - lead to, on the one hand, a consolidation within the group of boats over six meters and a gradual reduction of the type of fishery that relies on small catches caught from dinghies, dog-sledge and snow-mobiles. It is a new regulation that prioritizes a future fishery of a few larger and more efficient boats with access to a large amount of quota and presumably high profitability over a large group of smaller boats, dinghies, dog-sledges and snowmobiles producing on a relatively smaller scale. With regard to the ITQ segment the Minister also states elsewhere that 'no new company is to be granted a quota unless the quota is large enough to guarantee a whole year of sustainable fishing' (Sermitsiaq 10.06.2011). Somewhere along the way, a situation therefore must have emerged where the larger-scale mode of production achieved something close to a monopoly on the biological and economic sustainability leaving the smaller-scale fishery as the antithesis. How did this situation emerge? It is paradoxical that this majority of low-producing fishers come to represent a problem in terms of economic and biological sustainability if they are capable of supporting themselves based on a mixed economy and if their catches, put together, are not even close to exhausting the overall TAC. Nevertheless there are reasons for this problem to emerge in the way it did and the following sections analyses the process whereby this fishery became a governance problem as one that emerged out of three types of governmentality challenges which, from each of their direction, made it possible to think the small-scale fishery as problematic: an economic, a political and a moral one. 


\section{The political ungovernability of the coastal halibut fishers}

The coastal fishery presents a governance challenge to the current Minister of Hunting, Fishing and Agriculture, Ms Ane Hansen, in a number of ways. The above mentioned control challenges are good examples of the limits of a fishery systems' governability, but these were actually not the ones articulated during the decision-making process. A certain conflict in the TAC policy making, on the other hand, appeared as an underlying concern as implicitly reflected in the proposal referred to above. In line with what I have argued elsewhere the Fisheries Minister has since her appointment to the post become a symbol of a new fisheries governance paradigm that emphasizes biological sustainability higher than the former Siumut regime (Jacobsen and Raakjær 2012). But together with the workers in the processing industry and the Siumut party in opposition today, coastal fishers repeatedly manage to pressure the Minister to raise the coastal TACs beyond biological advice. Through formal as well as informal channels, they are able to exert a pressure that is hard to resist due to the very real social and economic consequences presented by closing down the only income opportunity for many people in the northern villages and towns. Elsewhere, I have characterized this decisionmaking process as 'fisheries co-politics' (Jacobsen and Raakjær 2012).

It has been argued that governance systems often face 'limits of governability' of the natural and social systems (Jentoft 2007). In the Greenland halibut case, however, it is not just that the social and natural system is 'ungovernable' in itself. It is also the political actions of the fishers within the governing system that is ungovernable. In a fisheries co-political system, the coastal fishers simply have too much 'unwanted' influence on the TAC decision-making vis-a-vis the current government aiming to govern according to a new governance paradigm, in a fisheries co-political system (Jacobsen and Raakjær 2012). In this analysis, the governmentality problem for the new paradigm in Greenlandic fisheries governance can also be analyzed as a problem of how to govern de facto co-governors. What we may really see in the new regulation is a process whereby one group - the government and its sustainability concerned constituency is replacing one group of co-governors for another: a few economically and biologically sustainable fishing companies for many politically powerful fishers. The governmentality concept of 'a conduct of conduct' may thus prove relevant in a Greenlandic fisheries governance context in the sense that subjects, at once powerful co-governors and objects of governance, that do not voluntarily exhibit the desired conduct are to have their political power reduced by actual exclusion from the fisheries. Just as much as governmentality manifests itself in acts of inclusion and cultivation, as has before been documented by other studies, so there also seems to be a 'limit to governmentality' that manifests itself in act of exclusion and eradication. And it seems to be because the TAC policy-making is characterized by confrontation between two adversary parties: a situation that does exactly not characterize the more consensual type of governance that goes by unnoticed and which can perhaps be said to characterize truly successful 'governmentality'. It is in this context, future exclusion becomes part of a long term planning solution. Thus, in response to fishermen's protest in October 2010 the Minister wrote a public letter to the newspaper Sermitsiaq in which she argued that the new regulation was part of an overall promise and need to find long term solutions: 
The government promised changes when we took over from the last elections. Notably changes that were based on careful evaluations and thorough analyses. Political zig-zag course and ad-hoc solutions that have not been thought through have throughout the years prevented long-term solutions in a range of areas with high costs for the Greenlandic society. It will stop now, we promised the voters and we stand by this. This naturally implies that all necessary changes must enter into an overall plan that does not only consider the wishes of some groups but the development of the entire society ... many initiatives have been taken following the necessary investigations. Actions that points forward. We can take the work we have put into long-term management plans as example. The important work was only started when we arrived. Now we are ready with a management plan for shrimp and management plans for Greenland halibut and cod are underway (Sermitsiaq 15.10.2010b).

The new governance paradigm in Greenland seems to understand itself in opposition to past paradigms. Long term management plans - as the 'new regulation' was originally perceived - are new in the Greenlandic context and may be perceived as a confrontation with the perceived ad-hoc solutions of earlier times. This attitude towards necessary and longterm solutions in fisheries are in line with the general discourse in Greenland planning and governance circles, where you repeatedly hear such sentences as 'status quo is not an option' and that 'ad hoc solutions will no more suffice'. These statements are put forward in relation to many of the debates on top of Greenlandic political agendas such as welfare (Skatte - og Velfærdskomissionen 2011, 17; Nathanielsen et al. 2010), regional development (the Regional Development Strategy) and fisheries (Premier's opening speech, 2010, 9). Judging from the assumed appeal of this rhetoric, the greatest crime, it seems, will be not to do something.

The main newspaper in Nuuk, Sermitsiaq, covered the development of the new regulation with interest (Sermitsiaq 10.06.2011) and provided discursive backing for the Minister's attempts at reforming the fisheries in line with the recommendations of the Fishery Commission, which I will return to below. In a critical editorial that deems the new government to have delivered little of the changes it promised, Ane Hansen is put forward the only one who has actually delivered by steering a hard-liner course towards reform and necessary change:

Ane Hansen has finally started to wear the trousers, shows who is in charge and she is about to get the fishery in order. But that she should have done two years ago when she had a fresh commission report and could have gone through with something which today could have been felt in Greenland's most important industry and which could have provided the promised feeling of change (Sermitsiaq 17.06.2011).

Fisheries managers tend to see the decision to reduce the small-scale fishery as an unpopular, problematic but indeed necessary next move. Not only is it necessary from a biological sustainability perspective, from a social perspective it also becomes a moral problem not to do something. The fishers were seen as caught in an inefficient fishery with a poor livelihood on public subsidies as a logical consequence. The working group managers understand their own and the Minister's role as that of being the unpopular guys that break down taboos as they push for an unpopular but necessary development 
while 'nobody dares to do anything' (personal observation of working group meeting). The WG managers were not alone charged with the key political decisions and so their perspective cannot explain entirely why the new regulation materialized as it did. But their understanding of the implementing mandate is telling of a dominant discourse in the context of the management of the fishery.

While the coastal fishery represents a challenge in terms of power and governance that becomes a problem of how to overcome general 'overcapacity' and the persistence of 'taboos', it's problematism is also couched in economic terms. The small-scale fishery is said to be unprofitable and increased profitability is the second goal of the new regulation. But how has this truth come to be?

\section{Economic governability - a standard set by the large scale fisheries}

The problem of profitability is central to many fishery discourses as described above. In the Greenlandic coastal fisheries this problem was also a dominant truth long before the new regulation perceived of it as the cause of a conservation problem. The problem of profitability and economic sustainability in the inshore fishery had been discussed in connection with an ongoing revision of the Greenlandic fisheries law (Fiskerikommissionen 2009; Regional Udviklingsstrategi 2011). 'Big is better' could be a slogan that covers the conclusions of the Fishery Commission which claims that resource rents paid by a very efficient fishing entity is the best way for a fishery to contribute to the national economy and hence, Greenlandic society. It is a discourse that weaves taxable income, Greenlandic future, international competition, efficiency and large scale modes of production together. Where the underlying numbers and calculations come from is difficult to assess, but as a closed argument the document stands strong and consistent as it at once performs and refers back to a coherent discourse.

Irrespective of its very foundation, the Fishery Commission's report of 2009 stands as a recent example of how the self-rule has chosen to look for answers in the big-scale production and capitalisation in its quest to develop Greenlandic fisheries. It is the most cited document in the work leading to the new regulation and in the work with the fisheries law reform that takes place in parallel to it. One of the central mandates of the commission was exactly to investigate the potential of the advantages of large-scale operations and the commission was able to conclude that there would be considerable advantages of large scale operations. In the Greenland halibut fisheries the advantages would befall to line-vessels with catch capacities between 800 to 5.000 tonnes per year on the condition that the current obligation to sell the fish to processors on land must is abolished (Fiskerikommissionen 2009). The commission also concluded that 'at least in the shrimp fishery as well as the Greenland halibut fishery, it is necessary with large vessel quota if the profitability shall be as good as possible' (Fiskerikommissionen 2009, 108-109).

The background paper for the new regulation shows that only one percent (equal to eighteen persons) of the participants in the coastal fishery for Greenland halibut sells more than hundred tonnes while forty-five percent of the fishers sell between five and thirty tonnes. Thus, serious concentration has to happen before the aforementioned considerable advantages of large scale production is reached according to the big-is-better discourse itself that estimated 800 tonnes to be the lower limit. Nevertheless, large scale production and consolidation is exactly what the new regulation for Greenland halibut is 
aiming at as it seeks to implement a reform through a process of concentration and increased profitability ensured by an ITQ regime. The Greenlandic sea-going shrimp fishery often serves as the implicit model for the necessary development in Greenlandic fisheries. In this sea-going shrimp fishery an ITQ system has been implemented with great consolidation effects reducing some fifty actors to only five today (FD manager, personal communication). Studies made back in 2003 (Rasmussen 2003) stated that the dominant discussions of the Greenlandic fisheries rests on the assumption that the sea-going shrimp fishery is the most important factor in the development of Greenlandic society. Export statistics confirm this assumption, but the assumption is, according to Rasmussen, flawed in the sense that it conflicts with the material and economic reality that local fleets, other fisheries and the subsistence economy are of great importance locally as well as nationally.

I have found, however, that the discourse on the relative contribution of different fisheries is riddled with contradictions. So for example, FD managers will acknowledge the importance of coastal fisheries while they in practice advocate their restructuring into something else. They will also claim that the Minister does not wish to out-phase the small-scale fisheries (FD managers, personal communication) and the Minister publicly states that she wish to emphasise that the reform is not an end to the fishery for Greenland halibut as we know it today. There will in the future be room for some of the existing actors' (Sermitsiaq 10.06.2011). On the other hand, I have on several occasions heard the leadership in FD say that 'one wishes to put an end to the small scale commercial fishery' - though it has never been completely clear to me who this 'one' is or are. In one and the same Parliament opening speech the Greenlandic Premier Mr. Kupik Kleist will also, on the one hand, recognize the importance of the present coastal fishery while shortly after, he will advocate its modernization by which it will, arguably, be turned into something else:

The population in villages and the outer districts are the ones that benefits most from the living resources based on fishing and hunting. They are to a considerable degree also contributing to the economic development of the country and we have great hopes for them. We from IA (political party) are content with the fact that the government is working diligently towards the realization of the new fisheries law (...) We in IA will work towards an economically sustainable fishing and hunting profession. The present structures within the fishing and hunting professions are unsustainable and therefore the need for reforms have been discussed for a long time (...) We need to adapt the profession and make it more competitive. We should be prepared to make certain tightenings and this should not be done through temporary ad hoc solutions. The fishing and hunting professions must be arranged to that they will also in the future secure a better outcome for the actors - through a sustainable solution (Kleist 2010, 8-9).

The decision-makers preference for ITQ should probably also be understood in the context of the general popularity of ITQs in fisheries governance discourse. Iceland is together with Norway the country Greenlandic politicians and managers look to for inspiration due to similarities in ecosystem and infrastructure challenges (personal observation). Indeed, a broad range of actors in Greenland seems to share a general belief in the promises of ITQ. The consultation answers of the companies that represent the 
sea-going and large-scale actors (Polar Seafood ltd., Royal Greenland ltd. and the Organization of Greenlandic Employers, GA) fully support the insertion of ITQ into the coastal halibut fishery. In their consultation answer to the new regulation they supported the new regulation with a steadfast belief in the universal superiority of the ITQ system that they based on what they perceived as an unambiguous historical truism. So GA claimed: 'History has shown that the (ITQ) model is best suited for creating the dynamic that leads to a structural reform that guaranties an economically sustainable fishery at fewest public expenses' (GA consultation answer 2011). Indeed, GA announced in an interview that it is only one step in the right direction and that its members would have preferred even further liberalization (Sermitsiaq 10.07.2011). KNAPK, the organization representing most coastal fishers supported the reform and the ITQ model at the beginning. The chairman did however emphasize that KNAPK wanted the quotas to remain on as many Greenlandic hands as possible in contrast to the large concentration seen in the Greenlandic shrimp industry (Sermitsiaq 24.06.2011). KNAPK's only concern and the reason why it did not support ITQ eventually was that they did not think that the Ministry's administration would be able to administer it effectively (KNAPK, personal communication) and the KNAPK chairman publicly supports the modernization of the coastal fishery that implies both more efficient and fewer vessels (Sermitsiaq 15.10.2010). As a manager in the FD observes, the Minister is neither the first nor the only one to promote the professionalization of the coastal fisheries, but she is at pains stating this view in public - something that may also explain the contradiction in the big-is-better discourses described above:

(A manager) explained to me that the Minister has announced that twenty percent of the fishers shall exit the fishery. Recently she has then added that this is to happen over a period of five to six years. It is however a little silly to blame her for this idea. The chairman of KNAPK has announced the same himself: We need a professionalization with less and better educated people. This is the official policy by KNAPK. A considerable amount of their members also agree - and (the manager) said he assumes nobody is in favour of that low an income. The problem is if the Ministry cannot announce that there is a need for education and a food foundation for those who continue in the fishery. The politicians in Northern Greenland feel uncomfortable with the restrictions the Ministry introduce to the fisheries otherwise they will be unpopular with their constituency (personal communication with FD manager).

In the Danish ITQ case Hegland and Raakjær (2008) argued that the ITQ model had been waiting for some time before the timing was right and a window of opportunity showed itself as two strong politician-actors promoted it. In the Greenlandic case one may argue in a similar vein that the new regulation as a decision-making occasion has provided nothing but yet another window of opportunity for the ITQ model to smoothly insert itself into yet another fishery. In Greenland, the ITQ model does not meet much resistance. Rather, there seems to be a dominant perception among government, fishery managers and formal stakeholder representatives that the ITQ-governed fishery provides Greenland with a historical national example of successful governance.

But there are counter discourses present that directly questions the 'big is better rationality' (Sermitsiaq 30-03.2011) and the advantages of a reduction of the number 
of fishers. After the Minister's announcement that twenty percent of the fishers were to leave the fishery, the fishers demonstrated in front of Parliament where they demanded the Ministers exit and stated "Ane, we are not numbers" (personal observation; Sermitsiaq 12.10.2010). Ten days later, a local fishers' representative from Ilulissat, Anthon Lindenhann, gave an interview to the national newspaper where he called for a port blockade in protest to the fact that the demonstration of the fishers had had no effect. He articulated a point of view that stands in opposition to the dominant discourse:

We are one of several fishing families in Ilulissat, who have handed over the family fishing business from the older to the younger generation and the new generation of fishers are ready. But there is great frustration as we feel that the fishery profession is to be out-phased. Everybody talks a lot about the oil and the job opportunities it will provide. But we are fishers and we would rather see our profession developed than out-phased. We have so many living resources that our politicians are unable to govern these riches. It is not only Greenland halibut we are thinking of. There are many different species which we do not use sufficiently. For example, we throw out the liver instead of producing it like other items. (Sermitsiaq 22.10.2010a).

I will argue that a certain trust in the claimed advantages of ITQ and large-scale production functions as a frame through which it becomes possible to view the small-scale fishery as inherently economically imperfect in the first place. As the new regulation explicitly states, the (first) goal of the new regulation is a structural reform of the fishery that will in the long run guarantee a number of participants in the fishery, which is economically profitable. By implication, the current fishers are not conducting the desired economic behaviour. Whereas the political governmentality problem evolved around the new governance paradigm being unable to control its co-governors in TAC policy making, the economic governmentality problem is a problem of how to outphase that which stands in the way for the necessary development and those who represent it. It is however, as if the dominant ideas of 'appropriate economic conduct' were beforehand shaped by the big-is-better rationality while competing perspectives, though marginally raised, have not entered the core documents of current fishery policy making of today such as the fishery commission report or the new regulation of the Greenland halibut fisheries.

\section{The planning governability of the poor}

From the perspective of power, a central question when it comes to the advantages of increased profitability and ITQ may be the question of advantage to whom? It is difficult to see how those to be excluded from the fishery will reap equal benefits from the new regulation. ITQ's have often been critiqued for the impacts it leaves on abandoned fishing communities and excluded fishers. In the context of the new regulation however, the truth of the small-scale fishery is constructed in a way so it poses the question of social fairness somewhat differently. It is important to understand this dimension of the new regulation though it is not stated explicitly anywhere, because it smoothens the very reform process through the dual construction of poverty and necessary moral action. It starts with a very dominant assumption about the small-scale fishery that is 
often articulated in informal conversations and public debates. It is, however, rarely supported by actual systematic documentation. The assumption is that the small-scale coastal fisheries in their current state do not make economic sense: They are politically powerful, and culturally and socially important, but they are not profitable and people 'cannot make a living out of it'. They are heavily subsidised and many of the coastal fishers get by only by help of welfare or they have a hard time getting by at all. It's a discourse that you find among managers in FD, at dinner tables in Nuuk, in political statements and public debates (Sermitsiaq 15.10.2010b). In the new regulation the income of the Fishers in the Greenland halibut fishery is one of the main arguments for the need for reform. Table 1 below presents one of the two tables that played a central role in supporting the implicit assumption that the fishery is not profitable enough as it is.

Whereas the background paper for the new regulation left the table to speak for itself, the Minister made the implicit explicit in a public letter:

Let me mention the coastal fishery for Greenland halibut as an example of the need for change: In this profession 150 vessels above eight meters and 1100 small entities in the form of dinghies, dog sledges and snow mobiles are dependent on the fishery. Sum-ups from 2009 concerning 1.268 fishers and hunters show that only $12 \%$ of these sold for over [26.851 Euros] and that a whole 63\% sold for less than [10.069 Euros]. Anyone can see that these are conditions that make it impossible to sustain an economically sensible livelihood without public subsidies - not to mention being able to afford material renewals and purchases within this fishery (Sermitsiaq 15.10.2010b).

The table reappeared in another major planning project, the Regional Development Strategy, where it was used to conclude that 'barely $2 / 3$ of those who sold Greenland halibut in 2009 sold for less than [10,069 Euros]. From this amount expenses to vessels, fuel, equipment et cetera must be deducted. On the other hand only 12 per cent had an income above [26,851 Euros] from the sale of Greenland Halibut' (Regional development Strategy, p 44). Another figure in the background paper served to show that the gross income of fishers in the northern municipality Qaasuitsup Kommunia - where most Greenland halibut fishers live - were 2,014 Euros lower than the average income of other citizens the Municipality and 7,250 Euro lower than the average male citizen in Greenland. The background paper notes that the value of country food for private

Table 1 Value from sale of Greenland halibut in 2009 (Source: ministry of fisheries, hunting and agriculture)

\begin{tabular}{llll}
\hline Value of sale (EUR) & Number of persons & Percentage of license-owners & Average value of sale \\
\hline $0-1,343$ & 289 & 23 & 514 \\
\hline $1,343-4,028$ & 223 & 18 & 2,565 \\
\hline $4,028-10,069$ & 288 & 23 & 6,940 \\
\hline $10,069-26,851$ & 316 & 25 & 16,299 \\
\hline $26,851-40,276$ & 54 & 4 & 32,424 \\
\hline $40,276-67,127$ & 39 & 3 & 52,440 \\
\hline $67.127-134.253$ & 49 & 4 & 95.383 \\
\hline More than 134.253 & 10 & 1 & 174.992 \\
\hline Total & 1.268 & 100 & \\
\hline
\end{tabular}


consumption, to which the fishers have more ready access, may in practice minimize the actual income gap. Still, the paper eventually concluded that 'generally, it can be concluded that the income if fishers in the coastal fishery for Greenland halibut is relatively low compared to the remaining part of the population' (Medlem af Naalakkersuisut 2011).

With the implicit assumption of poverty in the Greenland halibut fisheries as a backdrop, the new regulation seems to consider the negative social and economic impacts of ITQ as the lesser of two evils. The background paper for the new regulation states as one of the negative consequences of an ITQ system that 'those fishers who sell their quota will no longer be certain that they can have a job as fishers. This can potentially lead to greater unemployment among the fishers which can have considerable social and financial costs for the families of the fishers'. How can the new regulation, being aware of the high probability of these consequences in regions with few other employment opportunities than fisheries, eventually defend this? Whenever the discussion lands here, 'new growth-industries' are put forward as absorbers of the released fisheries labour. It is stated in the Fishery Commission's report and it was stated by the Minister when she for the first time publicly announced that twenty percent of the fishers were to leave the fishery (Sermitsiaq 07.10.2010).

Off-shore courses are in fact offered today and jobs are available at the explorations stage of what many hope will be continue into a regular Greenlandic oil industry. From a governmentality perspective one may argue that the out-phasing of small-scale fishers has as much to do with a strategy of creating new subjectivities of oil industry workers. As an example, the newspaper Sermitsiaq has taken on the responsibility of promoting this new opportunity for Greenlandic and Greenlandic workers (Sermitsiaq 29.04.2011). Still, the problem of the chicken and the egg seems stumblingly close in the context of fishery reform discussions: Are fishers to be offered a subjectivity as off-shore and mining workers because there will be a need for labour or is the expected growth-industries a convenient opportunity to legitimize the reduction that follows from concentration? A win-win situation certainly emerges within the discourse on a rhetorical level as the problem of necessary development meets the discursive reality of the poor. A question that is yet to be answered is whether the new regulation as a fisheries governance technique will succeed in its implementation. Implementation of conservation goals can be a very critical issue in fisheries governance in general (Gezelius and Raakjær 2008) and the new closure as well as the introduction of ITQ fishery may hypothetically create new subjectivities which the management did not foresee and whose behaviour may present new problems of control.

\section{Discussion}

Is the truth about the impossible economic situation of the small-scale fishery then the only truth? Within the fisheries department and the official discourse of high-level politicians in the Greenlandic government the answer appears confirmative. Other truths have not been allowed to function as truths and a very strong state of uncontested commonsense prevails. But in for example the descriptions of 'the hunting mode of production' provided by Dahl (2000), the livelihood approach in small-scale fisheries by Johnson et al. (2005), the economic strategies of hunters and fishers provided by Sejersen (2003) and the pan-arctic Survey of Living Conditions in the Arctic (SLiCA) (Poppel 2006), that aims 
to understand why people choose village life in spite of some statistically observable drawbacks, a competing discourse emerges that the small-scale fishery as a mode of organisation may actually make economic sense if approached from its own rationalities. A study of the social impact of the new regulation conducted in 2011 (Delaney et al.) arrives at similar conclusions. On the other hand I have spoken to quite a few public debate observers in Nuuk, who seem to know by heart the rhetoric of fishers and their representatives in Parliament when they assert pressure on the TAC by lamenting the fact that fishers will not be able to buy Christmas presents for their children. So the truth of the 'povertystricken' coastal fishers is also an effect of the strategy applied by fishers themselves in the TAC decision-making process. Thus it may be fair to say, that the representation of the coastal fishery as economically challenged is in reality constructed in perfect cooperation with (some) fishers and fisher representatives themselves in their political TAC strategies.

But no matter what the actual condition of the small-scale fishing economy, at the end of the day, the new governance paradigm is left with a limit-to-governmentality problem as it has to deal with what is at least perceived as a large group of coastal Greenland halibut fishers and their allies that are able to undermine a restrictive TAC policy. And not doing anything will not satisfy the perceived need for long-term planning to change what currently appears as the great 'other' in Greenlandic planning: ad hoc solutions and the status quo. And as long as poverty is the necessary antithesis to profitability measured in terms of monetary taxable income from the Greenland halibut fishery alone, the Minister and the administration have to pursue a governmentality technique that replaces small-scale subjectivities with large-scale ones as the very 'field of possible action' as a fisher is altered. This technique is the new regulation. The truth that underpins the need for action is, in the words of the dominant discourse, that this must be done for the sake of the small-scale fishers bound to poverty, for the sake of biological sustainability, for the sake of the national economy and for the sake of Greenlandic society at large.

Some observers of fisheries governance systems have noted that fishery governance systems have increasingly come to rely on the successful moulding of governable objects. And as other observers of the governability problem argue there are some highly ungovernable characteristics to the systems-to-be-governed - albeit more to some than others (Jentoft 2007; Jentoft and Chuenpagdee 2009a, 2009b; Song and Chuenpagdee 2010). In the Greenlandic case the ungovernable feature that may turn out to matter the most for the destiny of the small-scale Greenland halibut fisheries system might be their political ungovernability in a fisheries co-political system and the fact that they are the implicit antitheses to the dominant development discourse in Greenlandic fisheries governance that asserts that big is simply better. The conclusions of this case may foster a continuist's statement that history seems to be repeating. In spite of all the case-specific actors and actions, a structuralist observation creeps in that fisheries management almost takes place in mythic time and space and there is something archetypical to the characters of the 'ungovernable small-scale fishery' and to 'the control-seeking system' that governs it. And, as pertains to myths, the content of the narratives varies, but their underlying structure is one as for example the global ITQ victory march. But this Greenlandic case also illuminated the circumstance that the 'ungovernables' are not only ungovernable in their capacity of passive systems-to-begoverned. They are in fact political co-governors who themselves actively participate in 
and form part of the governance system. Thus the binary opposition between a governing system and a governed system is partly challenged in this fisheries co-political system. And I would argue that this is recognized as the new regulation becomes a technique for the new governance paradigm to make room for the cultivation of a new type of co-governors and extinguish the old type. Furthermore this article argues that the micro-tactics within the fishery policy arena over definitions of sustainability and the current compulsion to act, plan and reform - that do in fact characterize many fisheries governance systems - have been important drivers in this process.

In Foucault's original studies of the governance of 'bodies' and 'populations' the governors were never described as seeking to extinguish their subjects or giving up on governing them. One may present the counter-argument that that the new regulation is actually trying to govern the small-scale fisheries from a distance by bringing them into a more profitable larger-scale fishery. This is arguably likely to be the case for those who receive ITQ shares and who will be able to expand their production. On the other hand, a considerable number of persons are expected to leave or never to enter the fishery to make room for the profitability of the relatively few and profitable in the long term. In a fisheries governance context this 'limit to governmentality' appears as a peculiar mix of the brutality of technification and the humane. One speaks of technical fleet entities as 'small entities under six meters' while one acknowledges that what you govern - and what you save - is in reality humans. Paradoxically, politicians and managers can therefore work to out-phase fleets in order to save the humans that are not only socially and economically bound to the social and managerial reality of these categories, but who are also perceived of as being involuntarily caught therein.

\section{Endnote}

${ }^{a}$ At the time of publication the maximum ownership and its technical formulation is still being debated in Parliament.

Competing interests

The author declares that she has no competing interests.

Authors' contributions

RBJ concieved of the study, carried out the research and drafted the manuscript. The author read and approved the final manuscript.

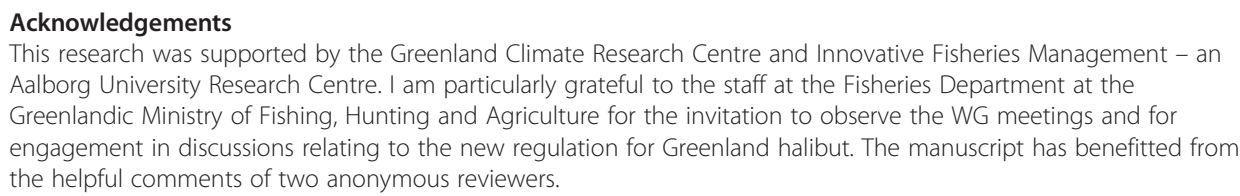


Delaney, A, K Hendriksen, and RB Jacobsen. 2011. Greenland Halibut in Upernavik: a preliminary study of the importance of the stock for the fishing populace. IFM working paper 214, Department of Development and Planning:: Aalborg University.

Fiskerikomissionen. 2009. Fiskerikommissionens Betænkning. Fiskerikommissionen. Grønlands Hjemmestyre [Danish]. www.nanoq.gl/Emner/Landsstyre/Departementer/Departement_for_fiskeri/ /media/ E03A2ECA9CBD4D45954B446C954D6963.ashx. Access date: August 4, 2011. [Danish].

Foucault, M. 1982. Afterword. The Subject and Power. In Michel Foucault: Beyond Structuralism and Hermeneutics, ed. HL Dreyfus and P Rabinow, 202-220. Great Britain: Harvester Wheatsheaf.

Foucault, M. 1994a. Governmentality. In Michel Foucault. Power. Essential works of Foucault 1954-1984. Vol 3, ed. JD Faubion, 201-222. London: Penguin Books.

Foucault, M. 1994b. In Michel Foucault. Power. Essential works of Foucault 1954-1984. Vol 3, ed. JD Faubion, 223-238. London: Penguin Books.

Gezelius, SS, and J Raakjær (eds.). 2008. Making fisheries management work. Implementation of policies for sustainable fishing. Reviews: Methods and Technologies in Fish Biology and Fisheries. Vol. 8:: Springer.

Government of Greenland, The Premier's Office. 2011. Redegørelse om Regional Udviklingsstrategi. http://dk.nanoq.gl/ Emner/Landsstyre/Departementer/Landsstyreformandens\%20Departement/RegionalUdviklingsStrategien/ /media/ EB19D59D17064BC28D571AEB232ECDA3.ashx. Access date: Auqust 4, 2011. [Danish].

Jacobsen, RB, and J Raakjær. 2011. A Case of Fisheries Co-politics? - Power and Participation in Greenlandic Total Allowable Catch Policy. Human Ecology. doi:10.1007/s10745-012-9458-7.

Jentoft, S. 2007. Limits of Governability: Institutional Implications for Fisheries and Coastal Governance. Marine Policy 31: $260-370$.

Jentoft, S, and R Chuenpagdee. 2009a. Fisheries and Coastal Governance as a Wicked Problem. Marine Policy 33: 553-560.

Jentoft, S, and R Chuenpagdee. 2009b. Governability Assessment for Fisheries and Coastal Systems: A Reality Check. Human Ecology 37: 109-120.

Johnsen, JP, P Holm, P Sinclair, et al. 2009. The Cyborgization of the Fisheries. On Attempts to Make Fisheries Management Possible.

Johnson, D, M Bavinck, and J Veitayaki. 2005. Fish Capture. In Fish for life: Interactive Governance for Fisheries, ed. J Koimann, S Jentoft, and P Roger. The Netherlands: Amsterdam University press.

Kleist, K. 2010. Åbningstale af Formanden for Naalakkersuisut. 21.09.2010 [Danish]. www.inatsisartut.gl/dvd/EM2010/pdf/ media/211802/pkt16_forside.pdf. Access date: August 4, 2011. [Danish].

Koimann, J (ed.). 2005. Fish for Life: Interactive Governance for Fisheries. Amsterdam, the Netherlands: Amsterdam University Press.

Mackinko, S, and DW Bromley. 2004. Property and Fisheries for the Twenty-First Century: Seeking Coherence from Legal and Economic Doctrine. Vermont Law Review 28(3): 623-61.

Masseym, ER. 2004. Sustainable Utilisation of Fisheries as Governmentality: Constraining the Potential for Ecosystemsbased Management? New Zealand Geographer 60(1): 25-35.

Medlem af Naalakkersuisut for Fiskeri, Fangst og Landbrug. 2011. Vedrørende regulering af det kystnære fiskeri efter hellefisk. 3. September 2011. [Danish].

Nathanielsen, N, N Thomsen and J Skade 27.05.2010 Status quo er ikke en mulighed [Danish]. Available: www.ia.gl/ index.php?id=1203. Access date: August 4, 2011. [Danish].

Pauly, D. 2008. 2008 Agreeing with Daniel Bromley. MAST 6(2): 7-22.

Pálsson, G, and A Helgason. 2000. Quota systems and ressource management: Icelandic fishing. http://www.thearctic.is/ articles/cases/quotasystems/enska/kafli_0700.htm. Access date: July 62012.

Poppel, B. 2006. Den Arktiske Levevilkårsundersøgelse, SLiCA - et komparativt og transnationalt projekt. In Grønland i verdenssamfundet, ed. H Petersen, 259-277. Greenland: Forlaget Atuagkat/llisimatusarfik [Danish].

Raakjær, J, and T Hegland. 2008. Implementation Politics. The case of Denmark Under the Common Fishery Policy. In Making fisheries management work. Implementation policies for sustainable fishing. Reviews: Methods and Technologies in Fish Biology and Fisheries (8), ed. SS Gezelius and J Raakjær, 161-205. London: Springer.

Rasmussen, RO. 2003. Havfiskeri/kystfiskeri - magt og afmagt i Grønlands hovederhverv. In Demokrati og magt i Grønland, ed. G Winther, 133-161. Denmark: Århus Universitetsforlag (Danish).

Roepstorff, A. 1998. Virutal Stocks, Experts and Knowledge Traditions. The Circulation of Knowledge on Greenland Halibut. In Aboriginal environmental knowledge in the North, ed. L-J Dorais et al., 95-122. Quebec: Gétic/Laval University.

Sejersen, F. 2003. Grønlands Naturforvaltning. Ressourcer og Fangstrettigheder. Denmark: Akademisk Forlag [Danish].

Sermitsiaq 30.03.201 Størst er ikke nødvendigvis bedst Available at www.sermitsiaq/node/79264. Access date: August 4, 2011. [Danish].

07.10.2010 Antallet af erhvervsfiskere skal reduceres kraftigt. Available: www.sermitsiaq.ag/node/76222. Access date: August 4, 2011. [Danish].

12.10.2010 Skænderi foran Inatsisartut Available: www.sermitsiaq.ag/node/76138. Access date: August 4, 2011. [Danish]

22.10.2010 Havneblokader under opsejling Sermitsiaq no. 42/52. 22.10.2010;3 [Danish].

15.10.2010a Ja til modernisering - nej til armod Sermitsiaq no. 41/52. 15.10.2010;7. [Danish].

15.10.2010b Fremtidens fiskeri skal skabe dynamik Sermitsiaq no. 41/52. 15.10.2010;42. [Danish].

29.04.2011 Sermitsiaq. No 17/53. [Danish].

10.06.2011 Fiskerireform i spil. Sermitsiaq no.20/53. [Danish].

24.06.2011 Bakker Ane Hansen op. Sermitsiaq no.25/53. [Danish].

Skatte - og Velfærdskommissionen 2011 Skatte- og Velfærdskommissionens Betænkning Marts 2011. Available: www. nanoq.gl/sitecore/content/Websites/nanog/Emner/Landsstyre/Departementer/Departement_for_finanser/ SkatteVelfaerdsKommissionen/Betaenkningen.aspx. Access date: August 4, 2011. [Danish].

Song, AM, and R Chuenpagdee. 2010. Operationalizing Governability: a Case Study of a Lake Malawi Fishery. Fish and Fisheries 11: 235-249.

Experiences with fisheries co-management in Europe. In The Fisheries Co.management Experience. Accomplishments, Challenges and Prospects, ed. Wilson.: Kluwer Academic Publishers. Fish and Fisheries Series 26. 
Symes, D et al. 2010 Experiences with fisheries co-management in Europe. In Wilson et al. The Fisheries Co. management Experience. Accomplishments, Challenges and Prospects. Kluwer Academic Publishers. Fish and Fisheries Series 26.

Valle, I, E Hoefnagel, K Astorkiza, I Astorkiza. 2006. Right-based fisheries management. In L. Motos and D.C. Wilson (eds.) The knowledge base for fisheries management. Developments in Aquaculture and Fisheries Science Series, Vol. 36, 85-108. Amsterdam: Elsevier.

Wadel, C. 1991. Feltarbeid i egen kultur. Flekkefjord: Seek A/S.

Wilson, DC, and RB Jacobsen, 2009. A Framework for fleet and area based fisheries management (AFRAME) project. EU Sixth Framework Programme Contract no.:044168. Deliverable 6.3. Available: http://www.ffm.dk/reports/200.pdf. Access date: August 4, 2011.

doi:10.1186/2212-9790-12-2

Cite this article as: Jacobsen: Small-scale fisheries in Greenlandic planning - the becoming of a governance problem. Maritime Studies 2013 12:2.

Submit your manuscript to a SpringerOpen ${ }^{\odot}$ journal and benefit from:

- Convenient online submission

- Rigorous peer review

- Immediate publication on acceptance

- Open access: articles freely available online

- High visibility within the field

- Retaining the copyright to your article

Submit your next manuscript at $\boldsymbol{\sim}$ springeropen.com 